\title{
Viewpoints, Perspectives or Letters to the Editor
}

\section{Introduction to section}

In line with international trends, the SAJEMS editorial board decided to introduce a section in the journal called: Viewpoints, perspectives or letters to the editor. We solicit submissions to this section that comprise novel concepts, ideas, or even a dialogue with either the editor or an author of an earlier paper either in SAJEMS or elsewhere. Controversial perspectives are even welcome, as long as they are presented in a constructive manner.

Submissions to this section are likely to be shorter than a conventional manuscript, varying from 1 page to approximately 2500 words. Submissions, though not necessarily qualifying in terms of all the rigorous requirements of a fully fledged scientific contribution, will nonetheless have to be robust and well motivated, and should be of relevance to scientific discourse and humanity.

We therefore see this section as an opportunity for senior scholars to provide insight into specific issues or ideas that are unlikely, or not ready, to take the form of a full scientific manuscript. We also see this as an opportunity for students and young scholars to share their research results from a less daunting (and belligerent) platform. Also, as is the case in this issue, we would like to see interesting information and research results, which could spark further discussions, based on a small sample survey.

I would therefore wish to extend an invitation to all our readers to submit shorter, focused, robust and well-articulated views, perspectives, comments, letters or papers to this new section.

Yours truly,

Steve Koch

Editor: SAJEMS 


\title{
REThinking ASGISA AND THE RAND EXCHANGE RATE
}

Willem H Boshoff

Department of Economics, University of Stellenbosch

\begin{abstract}
The ASGISA policy document identifies the exchange rate as one of the factors constraining accelerated growth in South Africa. This note argues that currency developments do not translate into business cycle movements in the aggregate economy, and that a weaker exchange rate is less likely to boost either foreign investment or export performance in the face of regulatory uncertainty.

The South African government has recently launched the Accelerated and Shared Growth Initiative (ASGISA) aimed at raising the long-term growth path of the economy. The plan identifies several so-called "binding constraints" that are considered to be inhibiting the economy from rising to more elevated levels of economic growth. One such "constraint", according to the ASGISA policy document, is the "volatility and level of the currency" (Republic of South Africa, 2006). By including this issue, policymakers have signalled that fluctuations in the rand are considered significant to broader economic fluctuations in South Africa. This research note questions such a conviction by offering evidence that currency fluctuations are not mirrored in the South African business cycle. Nonetheless, proponents may argue that a weaker rand will stimulate particular sectors, mostly those that are export-oriented, while it will boost Foreign Direct Investment (FDI). However, this note argues further that a weaker rand is less likely to generate sustainable improvement in either export-oriented industries or FDI in the absence of other reforms. The following sections consider these two issues in sequence.
\end{abstract}

JEL E32, F31, N17

\section{1}

\section{There is no general co-movement between the SA economy and the rand}

Proponents of the view that the currency is a "binding constraint" on growth rely on the effects of the 2001 rand depreciation, which fuelled exports and, perhaps more importantly, the subsequent deterioration in export performance as the rand appreciation gained momentum. However, this observation is not an adequate reflection of the larger body of empirical evidence.

Theoretically, currency developments should play an important role in South African industrial production as far as it affects exporters. Research on the relationship between South African financial variables and the business cycle broadly confirm this. Using a turning point cycle framework, similar to the one employed by the South African Reserve Bank (SARB) when dating the business cycle, Boshoff (2005; 2006) illustrates the relationship between the exchange rate cycle and the industrial production cycle. Table 1 reports the so-called concordance index (which can be interpreted as a correlation statistic) between these cycles for the period 1986-2004 (see Boshoff (2005; 2006) for details). The table contains results for cycles in both the levels and the twelvemonth growth rate of industrial production, and considers a lagged concordance of either six or twelve months between the exchange rate and industrial production cycles: 


\section{Table 1}

Concordance of South African exchange rates and industrial production

\begin{tabular}{|l|c|c|c|c|}
\hline & \multicolumn{2}{|c|}{$\begin{array}{c}\text { Concordance of industrial production } \\
\text { with 6-month lagged exchange rate }\end{array}$} & \multicolumn{2}{|c|}{$\begin{array}{c}\text { Concordance of industrial production } \\
\text { with 12-month lagged exchange rate }\end{array}$} \\
\hline $\begin{array}{l}\text { Exchange } \\
\text { rate } \\
\text { cycle }\end{array}$ & $\begin{array}{c}\text { Industrial } \\
\text { production } \\
\text { (levels) }\end{array}$ & $\begin{array}{c}\text { Industrial } \\
\text { production } \\
\text { (growth) }\end{array}$ & $\begin{array}{c}\text { Industrial } \\
\text { production } \\
\text { (levels) }\end{array}$ & $\begin{array}{c}\text { Industrial } \\
\text { production } \\
\text { (growth) }\end{array}$ \\
\hline $\begin{array}{l}\text { Real effective } \\
\text { rand (growth) }\end{array}$ & $-0.22^{*}$ & -0.11 & $-0.11^{*}$ & 0.20 \\
\hline $\begin{array}{l}\text { Real rand-dollar } \\
\text { (growth) }\end{array}$ & $0.48^{* *}$ & $0.09^{*}$ & $0.16^{*}$ & $-0.18^{*}$ \\
\hline
\end{tabular}

* Significant at $25 \% * *$ Significant at $15 \% * * *$ Significant at $5 \%$

The table confirms that, for the sample period, there is a statistically significant lagged comovement between cycles in the exchange rate and the industrial production cycle. The evidence is particularly strong when the real rand/dollar exchange rate is used. Appreciation phases in the currency therefore appear to have been followed by contraction phases in industrial production, while depreciation phases have resulted in expansions in industrial production. Nevertheless, it is important to note here that, while there appears to be a consistent empirical relationship, the direction of causality is not necessarily clear. For example, if exports are invoiced in foreign currency, then exchange rate depreciation will not necessarily improve exports. The causality issue is not pursued further here (see Du Toit et al., 2002) and MacDonald and Ricci (2004) for a discussion of plausible causal linkages).

How do these results compare when, instead of one output component such as industrial production, the aggregate South African business cycle is taken into consideration? Table 2 reports the results when both the official SARB business cycle and the GDP growth rate cycle are used.

Table 2

Concordance of South African exchange rates and the business cycle

\begin{tabular}{|l|c|c|c|c|}
\hline & \multicolumn{2}{|c|}{$\begin{array}{c}\text { Concordance of business cycle } \\
\text { with 6-month lagged exchange rate }\end{array}$} & \multicolumn{2}{c|}{$\begin{array}{c}\text { Concordance of business cycle } \\
\text { with 12-month lagged exchange rate }\end{array}$} \\
\hline $\begin{array}{l}\text { Exchange } \\
\text { rate cycle }\end{array}$ & $\begin{array}{c}\text { Official } \\
\text { SARB cycle }\end{array}$ & GDP growth & $\begin{array}{c}\text { Official } \\
\text { SARB cycle }\end{array}$ & 0.01 \\
\hline $\begin{array}{l}\text { Real effective } \\
\text { rand (growth) }\end{array}$ & -0.02 & 0.01 & 0.04 & 0.12 \\
\hline $\begin{array}{l}\text { Real rand-dollar } \\
\text { (growth) }\end{array}$ & 0.35 & 0.27 & 0.16 & \\
\hline
\end{tabular}

* Significant at $25 \% * *$ Significant at $15 \% * * *$ Significant at $5 \%$

None of the results are statistically significant (even at very generous 25 per cent levels). This is not due to the specific lag order (six or twelve months), as the results are unaltered for alternative choices of lag order ranging from zero months to eighteen months (Boshoff, 2006). Also, the results are not different for cycles in the levels (instead of the twelve-month growth rate) of the exchange rate. The same conclusions are reached when the nominal 
rand-dollar exchange rate is analysed. Figure 1 illustrates the lack of a consistent relationship by juxtaposing periods of acceleration and deceleration in GDP growth and similar upward and downward phases in the real rand/dollar exchange rate since 1995 (darker parts indicate upward movements). Clearly, there is no strong correspondence between upward phases in the exchange rate (i.e. depreciation phases) and acceleration phases in GDP growth. National GDP growth does not respond to the long depreciation phase starting at the turn of the century, and accelerates only from 2002, when the depreciation phase culminated in a rand crisis at the end of 2001. Furthermore, national GDP growth resumes acceleration towards the end of 2003, in the midst of a prolonged period of currency appreciation.



Source: Adapted from Boshoff (2006)

All in all, there is evidence for arguing that, while the exchange rate is of great importance for certain sectors of the South African economy, currency developments do not translate consistently into lagged cyclical movements in the aggregate economy. This evidence is supported by more extensive research on the prediction power of various South African financial variables. The general conclusion is that other financial variables, including the yield curve, fare better than the exchange rate in predicting business cycle developments in South Africa (Moolman, 2003).

These results are not unexpected. South Africa is an increasingly services-based economy, with the services sector accounting for 78 per cent of real GDP growth since 1994. The entire manufacturing sector, in contrast, has contributed approximately only 16 per cent of growth since 1994, while the sector's share of the total economy has continued to decline (du Plessis \& Smit, 2006: 4). It seems misguided to argue that the exchange rate, a famously difficult monetary policy target, could be used to permanently raise South African economic growth. Policy-makers should not be concerned about the performance of individual sectors, but should focus on overall economic performance. Such a policy focus would prevent special interest groups from influencing policy-makers towards pursuing policies that do not reflect the realities governing the economic system (and such captured policy focus may even undermine the productivity of that system (see North, 2006 for a discussion). 


\section{2}

\section{A weaker rand is not a panacea - and exchange rate targeting is difficult}

The previous section argued that, historically, gyrations in the rand have not translated into concomitant fluctuations in the national economy. Nonetheless, it could be argued that a weaker currency is important to export performance and may also boost FDI.

The ASGISA policy document implies that the rand has had a negative effect on investment: "[The currency is] overvalued in the sense that economic resources are diverted into narrow areas of investment, laying an unsteady foundation for the future" (Republic of South Africa, 2006: 4-5). This proposition is questionable. The above quotation supposedly refers to the lower levels of FDI, compared with portfolio investment flows. However, the conclusion in the literature (although tentative) is that exchange rate fluctuations play a much more pronounced role in the case of portfolio investments, while FDI flows depend more on the underlying structural parameters of the economy (du Plessis \& Smit, 2006). More generally, the hypothesis that the rand is misaligning South African financial markets is less plausible. Kantor and Barr (2006) show that the overall impact of exchange rate fluctuations on the performance of the South African share market is "moderate", noting that economic fundamentals drive returns in the long run. It is therefore not clear exactly which misalignment policy-makers are seeking to redress.

The South African mining industry offers a useful example to illustrate that the exchange rate is not the true "constraint", even in an export-oriented industry. The mining industry's relatively disappointing performance over the recent upswing in the commodity cycle is only partially attributable to exchange rate fluctuations. Instead, regulatory uncertainty and its significant costs appear to be the main sources of poor performance in the South African mining industry (The Economist, 2006: 66). Regulatory problems undermine the integrity of the institutional matrix of the economy, raising systemic risk and contributing to reduced investment. Consequently, if it is the government's aim to raise FDI or to boost export performance, it is the regulatory environment, and not necessarily the rand, that requires policy attention. Furthermore, insofar as the rand does have a role to play, it is informative to consider the conclusions of du Toit et al. (2002) who show that, at least since 1995, political risk factors appear to have offered at least a partial explanation for currency developments in South Africa. For this reason, if policymakers are really concerned about the volatility of the currency, it is essential to reduce policy uncertainty.

It is important to note that the inclusion of the exchange rate issue in the ASGISA document implies that a "remedial" policy is being planned. However, there are two problems here. Firstly, a policy response aimed at targeting the exchange rate is blind to South Africa's own historical experience, in particular, the SARB's failure to manage the rand during the early and mid-nineties. Du Toit et al (2002) show that previous attempts at using exchange controls to stabilise the currency have failed. In fact, these authors argue that attempts to manipulate the currency increased financial market uncertainty and may have had adverse long-term consequences, resulting in an exchange rate that deviates even further from the level preferred by policy-makers. Worse, when making statements about the value of the rand, policy-makers assume that they "know" the equilibrium value of the exchange rate. However, the latter continues to be a source of substantial disagreement among macroeconometricians (see MacDonald \& Ricci, 2004: du Plessis, 2005; MacDonald \& Ricci, 2005, for a discussion in the South African context). In fact, Frenkel (2007) provides econometric evidence that the recent appreciation of the rand is consistent with its past behaviour, noting that the evidence is not "in favor of the proposition that the rand was overvalued (as of early 2007) when judged by its own past relationship to economic fundamentals".

Secondly, even if it is argued that policymakers should aim to reduce the volatility of the rand (Kumo, 2006), such a policy response ignores the fact that the SARB has increased its 
involvement in the foreign exchange market in recent years. The SARB has been accumulating substantial foreign exchange reserves at a consistent pace since mid-2003, acquiring as much as $\$ 817$ million in reserves in December 2006 alone (Steyn, 2007). These purchases of dollar assets have continued despite the depreciation phase in 2006, indicating that the SARB may also favour a weaker currency. Consequently, the empirical evidence does not support the assertion that the SARB is not concerned about the exchange rate or is unable to influence its evolution. It is not clear why policy measures are sought (and the current monetary policy framework questioned) when monetary policy, in its current inflation targeting form, allows ample room for the SARB to influence the foreign exchange market. In fact, given that the exchange rate has a strong lagged correlation with the inflation rate, the external value of the rand is an important variable when the SARB is forecasting the path of inflation and contemplating monetary policy reaction.

\section{3}

\section{Conclusion}

If ASGISA is "a work-in-progress", as Parsons (2006) argues, it may be useful for future redrafts to exclude the rand as a "binding constraint". The rand is an important variable in exportoriented sectors, but there are other policy variables that are of much greater importance to both the economy in general and exporters in particular, such as regulatory certainty and its associated costs, which reduce investment and growth prospects. In addition, it is highly probable that attempts to target the exchange rate will fail, as the monetary policy history of South Africa and other countries suggest. It is encouraging that the ASGISA policy document does identify the regulatory environment as another "binding constraint" (Republic of South Africa, 2006: 5). However, a future re-draft of ASGISA should shift even more emphasis onto regulatory problems, issues that, arguably, represent the ultimate "binding constraints" on growth.

\section{References}

1 BOSHOFF, W.H. (2005) "The properties of cycles in South African financial variables and their relation to the business cycle", The South African Journal of Economics, 73(4): 694-709.

2 BOSHOFF, W.H. (2006) "The properties of cycles in South African financial variables and their relation to the business cycle," Department of Economics. Stellenbosch: University of Stellenbosch.

3 DU PLESSIS, S.A. (2005) "Exogeneity in a recent exchange rate model: A response to MacDonald and Ricci," The South African Journal of Economics, 73(4): 741-746.

4 DU PLESSIS, S.A. \& SMIT, B.W. (2006)

"Economic growth in South Africa since 1994,"

Working Paper 1/2006, Stellenbosch, Department of Economics: University of Stellenbosch.

5 DU TOIT, C.B.; BLACKMORE, F.; BRINK, S.M.; DE WET, W.A.; HARMSE, C.; JORDAAN, J.J.; MOOLMAN, H.C.; SCHOEMAN, N.J. \& STEYN, F.G. (2002) "South African exchange rate policy dilemmas," Focus on Economics Issues, Pretoria: University of Pretoria.

6 FRENKEL, J. (2007) "On the rand: Determinants of the South African exchange rate," The South African Journal of Economics, 75(3): 425-441.

7 KANTOR, B.S. \& BARR, G.D.I. (2006)

"The impact of the Rand on the value of the Johannesburg Stock Exchange," Journal of Studies in Economics and Econometrics, 29(2): 77-96.

8 KUMO, W.L. (2006) "Macroeconomic uncertainty and aggregate private investment in South Africa," The South African Journal of Economics, 74(2): 190-204.

9 MACDONALD, R. \& RICCI, L.A. (2004) "Estimation of the equilibrium real exchange rate for South Africa," The South African Journal of Economics, 72(2): 282-304.

10 MACDONALD, R. \& RICCI, L.A. (2005) "Exogeneity in a recent exchange rate model: a reply," The South African Journal of Economics, 73(4): 747-753.

11 MOOLMAN, E. (2003) "Predicting turning points in the South African economy," South African Journal of Economic and Management Sciences, 6(2): 289-303.

12 NORTH, D.C. (2006) Understanding the Process of Economic Change, Oxford, Princeton University Press.

13 PARSONS, R. (2006) "The accelerated and shared growth initiative for SA - Will it make a big difference to economic policy and economic 
performance?" Address to the University of Stellenbosch, 27 March 2006. Stellenbosch.

14 REPUBLIC OF SOUTH AFRICA (2006)

"Accelerated and shared growth initiative - South Africa," Pretoria.
15 STEYN, G. (2007) "Die Rand: Wensdenkery," Finweek, 18 January 2007 ed.

16 THE ECONOMIST (2006) "Undermined: Mining in South Africa," The Economist. 18 November 2006 (ed.). 


\title{
CALL FOR PAPERS: SA JoURNAL OF ECONOMIC AND Management STUdies (SAJEMS) ${ }^{1}$
}

\author{
SPECIAL ISSUE: NEW FRONTIERS IN STRATEGY \\ GUEST EDITOR
}

Johan Hough (jhough@sun.ac.za) University of Stellenbosch

CO-EDITORS

Ernst Neuland (mwneulnd@mweb.co.za) Institute for Business Innovation
Marius Pretorius (Marius.Pretorius@up.ac.za) University of Pretoria
Paul Sulcas (psulcas@gsb.uct.ac.za) University of Cape Town

Submission Deadline: September 15, 2008

A central focus of strategic management research and practice has been the development of concepts, models and tools to guide effective market-based, competitive strategies. Today, however, strategists face mounting external pressures from increasingly mobile, influential, new media savvy and demanding stakeholders. These increasingly diverse and changing groups of stakeholders are having a greater impact on competitive and corporate level strategies and on the practices of strategic management. These influences no longer are localized in their impact. They are felt on national, regional and global levels. Consequently, on-market strategies are being employed in an ever widening circle of market settings: agriculture, airlines, autos, bio-tech, chemicals, food processing, e-commerce, entertainment, natural resources, pharmaceuticals, retail, etc.

Trends of globalization of capital flows are increasingly expanding the influence of non-financial stakeholders (e.g., political, social, regulatory, legal) over company policy. These stakeholders also affect and shape performance expectations. In large public corporations, strategic plans are increasingly developed for consumption by non-market forces where the strategy discourse reflects non-market considerations. The time is ripe for an open and critical debate about the impact of strategies on strategic actions, competitiveness and performance.

\section{Types of Papers for this SAJEMS Special Issue}

This special issue aims at providing an opportunity for debate on the above-mentioned and related topics. We invite papers, including case studies, with different theoretical concepts, frameworks and methodologies, both empirical and theory-building. As this topic lies at the intersection of several subject domains, papers can draw from several fields, such as Strategy, Innovation, International Business, and Technology. Aspects of the phenomenon can also encompass other areas such as Entrepreneurship, Operations Research, Marketing, Finance, HR and Organisational Behaviour.

\section{Examples of Sub Topics that May Be Included in this SAJEMS Special Issue}

This special issue seeks to explore themes such as the ones shown below. The list below is not meant to be exhaustive, and authors are welcome to contribute papers with other perspectives as well.

- How can operational performance and benchmarking add to strategy implementation and competitiveness?

- How to implement Blue Ocean strategies through effective leadership and teamwork 
- How can companies create and capture new markets by using Strategic Maps and other implementation tools?

- Why are companies considering the off-shoring and/or outsourcing of core functions that comprise a firm's competitive advantage?

- What role do emerging markets like South Africa, India, Brazil, China, etc and/or emerging market firms play in the global outsourcing/off-shoring phenomenon?

- What precautionary mechanisms are being put into place to protect proprietary knowledge and capabilities of the firm to prevent the loss of future competitiveness?

- What is the role of global mergers and acquisitions and strategic alliances to ensure sustainable competitiveness?

- Business ethics and corporate governance as part of organisational strategy

- Strategic planning in knowledge-based industries and ventures

- Ownership, management and operational issues in family businesses

- Issues of particular significance to the future of South Africa including BBBEE, HIV/Aids, SME's, Triple Bottom Line

\section{Guidelines and Timeline for this SAJEMS Special Issue}

All manuscripts should be prepared according to SAJEMS "Instructions to authors" appearing after the Contents in a typical issue. Please submit manuscripts (not under review elsewhere) in electronic MSWord format to sajems@up.ac.za.

Deadline for papers for this SAJEMS Special Issue: September 15, 2008

Decision on acceptances for this SAJEMS Special Issue: March 15, 2009 